\title{
ADAMTS20 Gene
}

National Cancer Institute

\section{Source}

National Cancer Institute. ADAMTS20 Gene. NCI Thesaurus. Code C150165.

This gene is involved in both tissue-remodeling and proteolysis. 